\title{
Understanding Hearing Loss, Hearing Protection and Hearing Conservation Program: A Survey for Shipyard Field Managers
}

\author{
Cheol Min Yoon ${ }^{1}$, Junghwa Bahng ${ }^{1,2}$ \\ ${ }^{1}$ Department of Audiology and Speech-Langauge Pathology, Hallym University of Graduate Studies, Seoul, Korea \\ ${ }^{2}$ HUGS Center for Hearing and Speech Research, Seoul, Korea
}

\author{
조선소 현장 관리자의 청력손실, 청력보호, 청력보존 프로그램에 대한 이해에 관한 조사 연구 \\ 윤 철 민 ${ }^{1} \cdot$ 방 정 화 ${ }^{12}$ \\ 한림국제대학원대학교 청각언어치료학과', 한림청각언어연구소 ${ }^{2}$
}

\begin{abstract}
Purpose: Occupational noise-induced hearing loss (ONIHL) is the most common occupational disability. To decrease the number of $\mathrm{ONIHL}$, more accurate information on worker noise exposure is necessary to protect workers from job-related noise in the workplace. Thus, the present study aimed to analyze the current knowledge on hearing loss, the attitudes toward hearing protection, and more specifically, shipyard managers knowledge of hearing conservation programs. Methods: A 23-item questionnaire was designed to target shipyard field managers. The survey included questions about their knowledge of the causes and symptoms of hearing loss and the attitudes toward hearing protection and hearing conservation programs. A total of 115 shipyard field managers responded to the questionnaire. Results: The current results demonstrated that most of the respondents did not have enough knowledge of the causes and symptoms of hearing loss. However, they were more aware of the need to have good ear protection. Only $6 \%$ of the respondents knew about the hearing preservation program. Conclusion: If reducing ONIHL effectively, a hearing conservation program should be available and effectively educate every shipyard employees about the hazards of noise and related hearing loss and how to protect their ears actively from shipyard noise.
\end{abstract}

Key Words: Occupational noise induced hearing loss, Hearing loss, Hearing protection, Hearing conservation program.

Received: April 5, 2019 / Revised: April 9, 2019 / Accepted: April 9, 2019

Correspondence: Junghwa Bahng, Department of Audiology and Speech-Langauge Pathology, Hallym University of Graduate Studies, 427 Yeoksam-ro, Gangnam-gu, Seoul 06197, Korea

Tel: +82-70-8680-6933 / Fax: +82-2-3453-6618 / E-mail: bahng.jh@gmail.com

\section{INTRODUCTION}

소음성 난청은 직업병 중에서도 가장 많은 사람들이 겪는 질 병이다(Le et al., 2017). 작업장의 기계에서 발생하는 소리는 진 동과 큰 소리를 발생하게 되고 난청을 유발하는 요인으로 작용 한다. 소음성 난청은 일시적 혹은 영구적으로 발행할 수 있다. 전 세계적으로 직업적인 소음 노출로 인한 청력손실은 약 1 억 2 천만 명에서 2억 5000만 명이 발생할 것이라고 추정한다(Nel-

(c) This is an Open Access article distributed under the terms of the Creative Commons Attribution Non-Commercial License (https://creativecommons.org/licenses/by-nc/4.0) which permits unrestricted non-commercial use, distribution, and reproduction in any medium, provided the original work is properly cited. son et al., 2005). 국내 직업병 요관찰자(C1) 총 147,102명 중 직 업으로 인한 소음성 난청이 129,176 명(87.8\%)으로 제일 많았 으며, 직업병 유소견자(D1) 11,810명 중 소음성 난청이 11,456명 (97\%)으로 가장 많은 것으로 나타났다(Ministry of Employment and Labor, 2018). 미국 Occupational Safety and Health Administration의 보고에 따르면 약 22만 명의 근로자가 위험 이 될 만한 소음에 노출되어 있으며, 약 30만 명 정도는 청력손 실의 위험이 있는 이독성 화학물질에 노출되어 있다.

직업적인 소음성 난청은 근로자의 건강 문제와 함께 경제적인 손실을 초래할 수 있다. Neitzel et al.(2017)의 연구에서 소음성 난청자는 미국 전체 근로자의 $13 \%$ 에 이르며 연간 핵심 추정치 
로 1,230 억 달러 정도가 소음성 난청으로 인한 경제적 손실이 발생할 것이라 추정하였다.

직업 소음 노출로 인한 청력 상실은 개인의 전반적인 건강 상 태에도 영향을 미칠 수 있다. 난청이 발생한 근로자는 동료나 가족 간의 의사소통 장애로 인해 사회적 고립감에 시달리며 불 안감, 예민해짐, 자존감 저하 등의 심리적 문제를 야기할 수 있 다. Buksh et al.(2018)의 연구에 따르면 작업장 소음 노출 근로 자들의 경우 작업장에서의 지속적 소음으로 인하여 소음성 난 청이 발생하는 것은 물론 화, 스트레스 등의 심리적인 문제, 생 산력 저하, 혈압 상승과 같은 문제가 발생하는 것으로 나타났 다. 또한 van Kempen et al.(2002)은 소음 노출 근로자들을 대 상으로 한 43 개의 연구를 분석한 결과 혈압의 상승과 같은 유 의한 관계가 있으며 소음 노출 근로자의 경우 심혈관 질환, 협 심증 등에 대한 병을 상담하는 비율이 그렇지 않은 근로자보다 유의하게 높다고 보고하여 소음의 노출이 난청뿐 아니라 신체, 건강의 문제와도 연관이 있음을 밝혔다. $\operatorname{Kim}(2016)$ 은 지속적인 소음의 노출이 단속적 소음 노출보다 더 큰 장해를 초래한다고 하였다.

이러한 소음 노출 근로자의 소음 노출로 인하여 야기될 수 있는 여러 문제점으로 인하여 세계 각국은 작업환경의 소음 노 출 기준을 마련하고 있다. 우리나라 소음 노출 대상 산업체의 소 음 노출 기준은 8 시간 $90 \mathrm{~dB}(\mathrm{~A})$ 이며, $5 \mathrm{~dB}$ 교환율을 적용하여 $95 \mathrm{~dB}(\mathrm{~A})$ 일 경우 4시간, $100 \mathrm{~dB}(\mathrm{~A})$ 일 경우 2시간으로 규정하고 있다. 미국의 경우는(Occupational Safety and Health Administration, 2018) 우리나라와 동일한 허용 소음 수준을 규정하고 있다. 캐나다는 주마다 최대 허용 소음 수준 및 노출 기준이 다 르나 정부에서는 최대 소음 노출은 $87 \mathrm{~dB}(\mathrm{~A})$ 8시간으로 규정 하고 있고 $3 \mathrm{~dB}$ 교환율을 적용하고 있다(Canadian Centre for Occupational Health And Safety, 2018). Kim et al. (2010)의 연구에 따르면, 우리나라 대상 사업장 전체의 소음 노출 기준 초과율은 $12.19 \%$, 소음 노출 수준은 8 시간 가중 노출 평균값으 로 $84.68 \mathrm{~dB}(\mathrm{~A})$, 중앙값으로는 $83.91 \mathrm{~dB}(\mathrm{~A})$ 였으며, 사업장별 소 음 작업환경 측정 결과 시간 가중 평균 노출 기준(time weighted average)으로 측정 건수 중 하나 이상 초과한 사업장은 4,723 개 사업장(26.3\%), 측정 건수 중 초과한 건수가 $50 \%$ 이상의 초 과율을 보인 사업장은 2,045개(11.4\%)였다.

앞에서 언급한 바와 같이 상당수의 근로자가 소음에 노출됨 으로써 난청의 위험에 노출되어 있음에도 불구하고 소음성 난 청을 예방하고자 하는 노력에 대한 노력은 미비한 것으로 보인 다. Fuete \& Hickson(2011)의 연구에서는 아시아 지역 국가의 경우 미국, 유럽 등에 비해 소음성 난청에 대한 이해가 낮고 청 력보존 프로그램(hearing conservation program, $\mathrm{HCP}$ )의 실시 가 미흡하고 인식 또한 부족하다고 하였다. 우리나라에서는 과
다한 소음에 노출되는 근로자들을 대상으로 노동부령 제 195 호 산업보건기준에 관한 제 4 장의 소음 및 진동에 의한 건강장해의 예방에서 소음 노출 평가, 노출 기준 초과에 따른 공학적 대책, 청력보호구 지급 및 착용, 소음의 유해성과 예방에 관한 교육, 정기적 청력검사, 기록, 관리 등이 포함된 소음성 난청을 예방 관리하기 위한 종합적인 계획으로서 청력보존 프로그램을 시행 하고 있다(Korea Occupational Safety and Health Agency, 2005). 그러나 Lee(2017)의 연구에서는 소음 노출 근로자, 보건 관리자, 보건직 감독관을 대상으로 소음성 난청 예방 교육에 대 한 토의 및 면담을 진행한 결과 청력보존 프로그램의 중요성은 인식하고 있었으나 소음의 노출이 생명과 직결되는 사항이 아 니기 때문에 형식적으로 이루어지고 있는 것으로 나타났다.

기존 선행연구(Colbeth et al., 2019)에서는 주로 일과의 대부 분이 소음에 노출된 또는 소음환경에서 작업하는 근로자들을 대상으로 한 연구가 많이 이루어졌다. 그러나 이러한 소음환경 을 관리하고 근로자들에게 적극적인 소음 노출에 대한 관리를 해야 하는 직종은 바로 현장 관리자들이다. 현장 관리자는 소 음 노출 근로자들을 관리하고, 작업환경의 소음 노출에 대하여 인지를 해야 하는 입장이기도 하며 스스로가 소음 노출 근로자 이기도 한다. 현재까지 소음 노출 현장의 관리자들을 대상으로 한 난청 혹은 소음 노출 인식 등에 관한 연구는 현재까지는 이 루어지지 않았다. 본 연구는 조선소 내 현장 관리자에 맞는 적 절한 항목과 문항으로 구성된 설문지를 통하여 조선소 내 현장 관리자의 '청력손실 원인과 증상에 대한 이해', '청력보호에 대 한 태도', 그리고 '청력보존 프로그램의 이해’에 관한 질문을 통 해 실태파악을 목적으로 한다. 본 연구결과를 통해서 소음 노출 근로 근무 환경에서 형식적인 예방 교육이 아닌, 실질적인 예방 교육 및 개선에 대해 참고가 되길 바란다.

\section{MATERIALS AND METHODS}

\section{연구 대상}

본 연구는 2018년 9월 3일부터 11월 12일까지 울산 내 H 조선 소에 근무하는 생산 및 품질 관리자 27세에서 42세까지 120명 을 대상으로 전체 동의하에 설문조사를 실시하였다. 이 중 설문 문항 가운데 모든 문항에 응하지 않은 5 명의 설문 응답지를 제 외하여 최종 115 명에 대한 응답 결과를 분석하였다. 대상자들의 평균 근무 기간은 평균 7.15년을 근무하고 있으며, 근무자가 느 끼는 하루 체감 평균 소음 노출시간은 3.7시간으로 나타났다. 그 외 대상자의 일반적인 특성은 다음 Table 1 에 제시하였다.

\section{설문 구성}

설문지는 사회력, 과거 질병력 4 문항, 현재 근무지에서의 소 
음 노출 관련 3 문항을 기본적인 대상자 정보를 위하여 질문하 였다. 조선소 현장 관리자의 소음 인식 조사를 위해 사용한 설문 지는 Lee \& Bahng(2016)에서 설문 문항 41문항 중 11문항만을 사용하였다. 이 중 9 문항은 청력손실의 원인, 증상, 청력손실 예 방 방법에 관한 이해이며, 2 문항은 청력보호를 위한 태도에 관한 질문으로 구성하였다. 그리고 5 문항은 청력보존 프로그램 자체 의 인지 여부, 청력보존 프로그램의 이해에 대하여 파악하기 위 해 작업장 소음 레벨, 보호구 착용 방법, 소음 건강장해, 그리고 청력검사 결과 이해에 관한 문항으로 구성하였다. 총 23 문항으 로 설문지는 조선소에 근무하는 현장 관리자 30 대 중반 3 인을 대상으로 예비조사 실시 및 적절성을 검증하였다. 청력손실 원인 의 이해에 관한 항목 9문항의 경우, "그렇다(Yes)", "아니다(No)", “모르겠다(Don't know)"로 답변하도록 하였다. 마지막 작업장 소 음과 보호구 인식 관련 7문항의 경우, "그렇다(Yes)", "아니다 (No)", "확실히 잘 모르겠다(Yes, but not sure)"로 답하였다. 해 당 설문은 Appendix에 제시하였다.

\section{통계 분석}

설문 자료의 분석 방법은 SPSS version 25 (IBM Corp., Ar-

Table 1. Characteristics of 115 participants responded in the study

\begin{tabular}{|c|c|}
\hline Characteristics & Number of respondents (\%) \\
\hline \multicolumn{2}{|l|}{ Sex } \\
\hline Male & $111(96.52)$ \\
\hline Female & $4(3.48)$ \\
\hline \multicolumn{2}{|l|}{ Age (year) } \\
\hline$<30$ & $5(4.35)$ \\
\hline $30-34$ & $43(37.39)$ \\
\hline $35-40$ & $55(47.83)$ \\
\hline$>40$ & $12(10.43)$ \\
\hline \multicolumn{2}{|l|}{ Alcohol history } \\
\hline Never & $26(22.61)$ \\
\hline Sometimes (once 1-2/week) & $75(65.22)$ \\
\hline Often (more than 3/week) & $14(12.17)$ \\
\hline \multicolumn{2}{|l|}{ Smoking history } \\
\hline Never & $47(40.87)$ \\
\hline Current & $50(43.48)$ \\
\hline Former & $18(15.65)$ \\
\hline \multicolumn{2}{|l|}{ Otological history } \\
\hline Hearing loss & 0 \\
\hline Tinnitus & $8(6.96)$ \\
\hline Otitis media & 0 \\
\hline Tympanic membrane perforation & 0 \\
\hline Facial nerve palsy & $1(0.87)$ \\
\hline Meniere's disease & 0 \\
\hline Tympanic membrane plastic surgery & $2(1.74)$ \\
\hline None & $104(90.43)$ \\
\hline
\end{tabular}

monk, NY, USA)를 이용하여 조선소 현장 관리자의 인식 수준 및 인식도의 모든 문항에 대하여 기술통계를 사용하였다.

\section{RESULTS}

본 연구에서는 조선소에서 현장 관리자 115명을 대상으로 청 력손실 원인의 이해와 청력보호에 관한 인식, 소음 노출에 대 한 설문지를 분석하여 조사하였다.

\section{청력손실 원인과 증상에 대한 이해}

청력손실의 원인과 증상에 대한 이해에 대해서는 총 9문항으 로 구성하였다. "그렇다", "아니다", "잘 모르겠다”라고 답변하도 록 하였다.

2, 3, 4번 문항의 경우 “그렇다”라고 답을 하는 경우, 나머지 문항은 "아니다"라고 답을 하는 경우 청각적 지식을 잘 이해하 고 있다고 판단할 수 있다. Table 2는 청력손실의 원인과 증상 에 대한 이해 항목에 대한 결과이다. 청력 문항 1 번의 경우 청 력손실이 있는 사람의 경우 “청력손실을 가지고 있는 사람은 이미 청각기관이 손상이 돼서 유해한 소음 수준에 대해 염려하 지 않을 것이다"라는 항목에서 “아니다"라고 답한 경우가 더 많 았지만 이 부분에 대해 잘못 인지하고 있거나 모른다고 답한 경우 또한 약 $33 \%$ 에 해당하였다. 다음 "소음 때문에 발생한 청 력손실은 예방할 수 있었다"의 답변에서는 "그렇다"라고 대답 한 답변이 약 $52 \%$ 에 달하였다. 이는 청력손실을 막기 위하여 소음으로부터 귀를 보호해야 한다는 의식을 약 절반 정도만 가 지고 있는 것으로 해석할 수 있을 것이다. "귀에서 윙윙 울리는 것은 유해한 소리의 과다노출에 대한 경고 신호이다”라는 질문 에는 $70 \%$ 이상이 “그렇다"라고 답을 하여 과도한 소음 노출 시 증상에 대해서는 문제의식을 가지고 있는 것으로 나타났다. "상대방의 음성이 작거나 웅얼거리게 들리면 청력에 문제가 있 을 것이다" "TV나 라디오의 볼륨을 높이는 것은 청력에 문제 가 있을 것이다" 각각 약 $79 \%, 10 \%$ 가 “그렇다”라고 답을 하여 난청이 발생한 후의 증상에 대해서 이해하고 있는 바가 상반된 결과를 보였다. 음성이 작게 들리는 것은 난청이 발생했을 수 있다는 위험이 있으나, TV나 라디오 볼륨이 높아지는 것은 난 청의 증상으로 느끼지 못하는 것으로 분석하였다. "주변에 자 주 큰 소리가 나더라도 내 귀는 스스로 청력을 보호할 수 있는 능력이 있다"라는 질문에는 “모르겠다"라고 답한 경우가 $46 \%$ 정도로 귀에 대한 정보가 부족한 것으로 나타났다. "큰 소리에 의한 청력손실이 발생한 사람은 보청기를 착용하면 정상적으 로 들을 수 있다", "큰 소리에 의한 청력손실이 발생한 사람은 소리가 커지면 정상적으로 들을 수 있다"의 질문에 청력의 손 실이 있더라도 보청기를 착용하면 약 $47 \%$ 는 잘 들을 수 없다 
Table 2. Respondents distribution for nine questions about the knowledge of hearing loss

\begin{tabular}{|c|c|c|c|}
\hline Items & $\begin{array}{c}\text { Yes } \\
\mathrm{n}(\%)\end{array}$ & $\begin{array}{c}\text { No } \\
\mathrm{n}(\%)\end{array}$ & $\begin{array}{c}\text { Don't know } \\
\mathrm{n}(\%)\end{array}$ \\
\hline $\begin{array}{l}\text { 1. Do you think that people who have pre-exiting hearing loss do not have to worry about } \\
\text { future hazardous noise level, because the damage has already been done? }\end{array}$ & $14(12.17)$ & $77(66.08)$ & $25(21.74)$ \\
\hline 2. Do you think that hearing loss caused by noise can be prevented? & $60(52.17)$ & $20(17.39)$ & $35(30.43)$ \\
\hline $\begin{array}{l}\text { 3. Do you think that ringing in the ears is a warning sign for over exposure to potentially } \\
\text { hazardous sound? }\end{array}$ & $85(73.91)$ & $6(5.21)$ & $24(20.86)$ \\
\hline 4. Is "voice sounding muffled or mumbled" a sign of hearing loss? & $91(79.13)$ & $9(7.82)$ & $15(13.04)$ \\
\hline 5. Is having to turn up the volume on TVs or radios a sign of hearing loss? & $12(10.43)$ & $78(67.82)$ & $25(21.74)$ \\
\hline 6. If I'm around loud sounds often, my ears can adjust and help protect my hearing. & $29(25.22)$ & $33(28.70)$ & $53(46.09)$ \\
\hline $\begin{array}{l}\text { 7. People with hearing loss caused by loud sounds can hear normally again if they wear a } \\
\text { hearing aid. }\end{array}$ & $24(20.87)$ & $54(46.96)$ & $37(32.17)$ \\
\hline $\begin{array}{l}\text { 8. People with hearing loss caused by loud sounds can hear normally again if they turn up } \\
\text { the volume. }\end{array}$ & $21(18.26)$ & $71(61.74)$ & $23(20.00)$ \\
\hline $\begin{array}{l}\text { 9. A good way for people to protect their hearing from loud sounds is to put cotton or } \\
\text { tissue in their ears. }\end{array}$ & $22(19.13)$ & $63(54.78)$ & $30(26.09)$ \\
\hline
\end{tabular}

Table 3. Respondents distribution for two questions about the attitude of hearing protection

\begin{tabular}{lccc}
\hline \multicolumn{1}{c}{ Items } & $\begin{array}{c}\text { Yes } \\
\mathrm{n}(\%)\end{array}$ & $\begin{array}{c}\text { No } \\
\mathrm{n}(\%)\end{array}$ & $\begin{array}{c}\text { Yes, but not sure } \\
\mathrm{n}(\%)\end{array}$ \\
$\begin{array}{l}\text { 1. Spending time learning about hearing loss and protecting my hearing would be } \\
\text { valuable to me. }\end{array}$ & $111(96.52)$ & $1(0.87)$ & $3(2.61)$ \\
2. I see value in spending money to protect my hearing. & $108(93.91)$ & $0(0)$ & $7(6.09)$ \\
\hline
\end{tabular}

Table 4. Respondents distribution for five questions about the knowledge of hearing conservation program

\begin{tabular}{lccc}
\hline \multicolumn{1}{c}{ Items } & $\begin{array}{c}\text { Yes } \\
\mathrm{n}(\%)\end{array}$ & $\begin{array}{c}\text { No } \\
\mathrm{n}(\%)\end{array}$ & $\begin{array}{c}\text { Yes, but not sure } \\
\mathrm{n}(\%)\end{array}$ \\
\hline 1. I've heard about “hearing conservation program.” & $7(6.09)$ & $90(78.26)$ & $18(15.65)$ \\
2. I’ve heard and understood the noise level of the work place. & $49(42.61)$ & $25(21.74)$ & $41(35.65)$ \\
3. I know how to wear hearing protectors and precautions. & $65(56.52)$ & $15(13.04)$ & $35(30.43)$ \\
4. I know what I need to prevent noise and health problems. & $25(21.74)$ & $44(38.26)$ & $46(40.00)$ \\
5. I understand results of my hearing test and medical diagnosis. & $68(59.13)$ & $12(10.43)$ & $35(30.43)$ \\
\hline
\end{tabular}

고 대답한 반면 “볼륨을 높이면 정상적으로 들을 수 있다”라고 묻는 질문에는 약 $62 \%$ 가량이 잘 들을 수 없다라고 대답하여 청력손실 후 재활에 대한 이해가 부족한 것으로 나타났다. 마 지막으로 "면이나 휴지를 귀에 넣는 것은 커다란 소리로부터 청력을 보호하는 좋은 방법이다”의 질문에 “아니다”라고 답한 경우가 55\%에 해당하였다. 그러나 “모르겠다”라고 답변한 경우 가 $26 \%$ 로 귀를 보호하는 방법에 대하여 이해가 부족한 것으로 나타났다.

\section{청력보호에 대한 태도 및 청력보존 프로그램의 이해}

청력보호에 대한 태도는 2문항, 청력보존 프로그램의 이해에 관한 항목은 5항목으로 구성하였다. 본 문항들은 귀를 보호해 야 한다는 필요성에 대한 인식과 연구 대상자가 근무하고 있는 작업장 소음, 그리고 보호구 착용 등에 대한 중요성 등에 대한
질문으로 구성하였다. 답변은 “그렇다", "아니다", "확실히 잘 모 르겠다”라고 구성하였다. “확실히 잘 모르겠다”라는 답변에는 많은 대상자들이 "그렇다", "아니다"로 확신할 수 없는 경우 답 변하도록 하였다.

Table 3은 청력보호에 대한 태도 항목에 대한 결과이다. "청 력손실 방지에 대하여 노력하는 것은 가치가 있다"와 “청력손 실 방지를 위하여 돈을 쓸 가치가 있다"의 질문에 대해 “그렇 다"는 답변은 $96.52 \%, 93.92 \%$ 로 상당수가 귀 보호의 필요성을 인지하고 있는 것으로 나타났다.

Table 4는 청력보존 프로그램에 대한 이해 항목에 대한 결과 이다. "청력보존 프로그램에 대해서 들어본 적이 있다" 항목에 약 $78 \%$ 는 들어본 적이 없다고 대답하였으며 약 $6 \%$ 만이 청력보 존 프로그램이 무엇인지 들어본 적이 있다고 대답하였다. "내가 일하는 곳의 소음 레벨을 알고 있고 그 크기의 수준을 이해하 
고 있다"의 질문에는 약 $42 \%$ 만이 알고 있다고 대답하였고 나머 지는 모르고 있거나 확실하지 않게 알고 있는 것으로 대답하였 다. “소음 건강장해 방지에 필요한 사항에 대해 알고 있다"는 질 문에 대해서는 약 $78 \%$ 가 모르거나 제대로 알지 못한다고 대답 하여 인식이 부족함을 나타내었다. 소음 노출 근로자들의 경우 청력검사를 반드시 받도록 되어 있어 그 결과에 대하여 제대로 이해하는가에 관한 질문도 있었다. 이 문항에서는 약 $59 \%$ 만이 알고 있다고 대답하여 각자의 청력검사에 대하여 이해가 필요한 것으로 나타났다.

\section{DISCUSSIONS}

본 연구에서는 지속적 소음이 과도하게 노출되는 조선소 사 업장 내 관리자 115 명을 대상으로 소음, 청력손실 및 청력보호 구에 관한 인식을 설문조사를 통해 실시하였다. 현장 관리자는 소음 노출 근로자들을 관리하는 입장으로 소음 노출에 대하여 작업자들보다 먼저 인지를 해야 되는 입장이기도 하며 스스로 가 소음 노출 근로자이기도 한다. 이에 연구의 목적은 다음과 같다. 조선소 내 현장 관리자에 맞는 적절한 항목과 문항으로 구성된 설문지를 통하여 '청력손실 원인과 증상에 대한 이해', '청력보호에 대한 태도', 그리고 '청력보존 프로그램의 이해'에 관 한 질문을 통해 실태파악을 하고자 하였다.

연구결과에 따르면 대상자들의 '청력손실의 원인과 증상에 대한 이해'에 대한 분석 결과 청력손실에 대한 이해는 전반적으 로 좋지 않은 것으로 나타났다. Danhauer et al.(2012)의 고등학 생 대상 답변에는 $88.9 \%$ 정도가 소음과 청각 손실에 대하여 이 해력을 보였다. 본 연구에서는 본 연구에 참여한 대상자의 결과 를 비교해 볼 때 전반적으로 “모른다"라는 대답이 9문항 모두 에서 $20 \%$ 이상을 나타냈으며, 문항 4,5 번에서는 비슷한 질문 을 물음에도 불구하고 상반된 결과를 보여 난청의 증상에 대 한 이해가 낮은 것으로 보였다. 문항 4번에서는 상대방의 목소 리가 작거나 웅얼거리게 들리면 대상자 대부분이 난청이 있다 고 의식한다는 답을 하였으나, 문항 5 번에서 TV나 라디오 볼 륨을 높이는 것은 청력에 문제가 있는가 묻는 문항에서는 난청 과 TV, 라디오의 볼륨과는 상관이 없다는 대답이 다수였다. 대 상자 대부분이 TV 혹은 라디오 볼륨의 크기는 난청과 상관없 이 개인적인 선호도라고 추측하여 답한 것으로 추정할 수 있 다. 또한 정상청력의 경우 큰 소리에 스스로 귀를 보호하는 기 능이 있음에도 불구하고 이러한 큰 소리에 잦은 노출이 될 경 우 귀를 보호하는 능력이 감소하여 난청이 발생할 가능성이 높 아진다. 이에 대한 지식을 묻는 질문인 7번 문항에서는 약 $46 \%$ 정도가 “모르겠다"라고 답을 하여 이에 대한 이해가 낮은 것으 로 나타났다. 또한 약 $52 \%$ 정도만이 소음으로 인한 난청은 예
방될 수 있다고 대답을 하여 소음 노출에 대한 난청을 적극적 으로 예방하기 위한 교육이 필요할 것으로 분석하였다. 그러나 큰 소리 노출 후 발생하는 이명이 소음 노출에 대한 위험 경고인 가에 대한 질문에는 약 $73 \%$ 가 “그렇다"라고 답을 하여 이에 대 한 이해는 잘하고 있는 것으로 나타났다.

조선소는 소음성 난청이 발생할 만큼의 강도 높은 소음이 발 생하는 작업장이다. 소음의 작업환경 측정 결과 소음 수준이 $90 \mathrm{dBA}$ 를 초과하는 사업장이거나 소음으로 인하여 근로자에 게 건강장해가 발생한 사업장에 관하여 산업안전보건기준에 관한 규칙 제517조(청력보존 프로그램 시행 등)에 따라 청력보 존 프로그램을 실시하여야 한다. 한국산업안전보건공단의 청력 보존 프로그램의 수립 및 시행지침에 따르면 '청력보존 프로그 램의 목적은 소음성 난청을 예방하고 관리하기 위하여 소음 노 출을 평가, 노출 기준 초과에 따른 공학적 대책, 청력보호구의 지급 및 착용, 소음의 유해성과 예방에 관한 교육, 정기적 청력 검사, 평가 및 사후관리, 문서 및 기록, 관리 등을 포함한 종합 적인 계획을 의미한다. 이러한 청력보존 프로그램에는 소음성 난청 예방 교육이 포함되어 있어야 하며 교육의 내용에는 소음 의 유해성과 인체에 미치는 영향, 청력보호 보호구의 착용 목 적, 장단점, 착용 방법 및 주의사항, 청력검사의 목적, 방법, 결 과의 이해와 사후관리 등이 포함되어야 한다. 본 연구결과를 볼 때에 청력보존 프로그램은 물론 소음성 난청 예방 교육이 제대로 이루어지지 않은 것으로 본다.

Lee(2017)의 선행논문에서는 형식적으로 교육이 진행된다는 점과 생명과 직결되는 사항이 아니라 최우선적인 현안과제로 인지하고 있지 않다는 내용을 서술하고 있다. 이에 해당 논문 에서 조사한 설문결과도 마찬가지로 밀접하게 인지가 많이 부 족한 것으로 보여 개선이 필요하다고 분석하였다. '해당 작업 장소의 소음 수준에 대해서 설명을 들었고 인지하고 있다', '청 력보호 기기의 착용 방법 및 주의사항에 대해 알고 있다' '본인 의 청력검사 및 의학적 판정에 대하 이해하고 있다 항목은 각 항목당 대상자의 $50 \%$ 전후가 인지를 못하는 결과를 보이고 있 다. 또한 소음장해 관련하여 Korea Industrial Health Association(2003) 내용과 같이 소음, 진동 및 분진에 의한 건강장해 예방 조치가 진행되어야 한다고 표기되어 있으나, '소음 건강장 해 방지에 필요한 사항에 대해 알고 있다의 결과는 $78.26 \%$ 가 소 음 건강장해에 대하여 인지가 부족하고 소음 건강장해 방지 내 용 자체를 이해하지 못한 채 답변한 반응을 보이고 있다.

Bhumika et al.(2013)의 연구에 따르면, 인디아 조선소 근무 자 276명과 나이와 성별을 매치한 비대조군 276명과 비교한 결 과 청력보호구를 가끔 사용한다고 대답한 $6 \%$ 및 전혀 사용하 지 않는다고 대답한 $21 \%$ 에서 소음성 난청이 발생한 것으로 분 석하였다. 본 연구결과로 미루어 볼 때 청력보호구의 사용에 관 
한 교육은 소음성 난청을 적극적으로 예방할 수 있는 가능성을 시사한다. 또한 본 논문의 설문결과에서 대부분의 답변자가 귀 를 보호하는 것은 가치 있는 일이라고 답변을 했으며 청력보호 구에 돈을 쓸 가치가 있다고 답변을 하여 청력을 보호하고자 하는 태도는 긍적적으로 나타났다.

본 연구에서는 소음 노출 관리자들을 대상으로 소수로 진행 하였지만 설문을 통해 청력손실과 보호에 관한 관심을 조금이 라도 갖게 하는 계기가 되었다는 것에 의의를 찾을 수 있다고 본다. 또한 설문에 응한 대상자들은 소음 노출 근로자이면서 소음 노출 근로자들의 관리자이므로 이들의 의식 개선이 중요 하다고 할 수 있다. 직업적으로 노출된 소음으로 인한 소음성 난청을 줄이기 위해서는 청력보존 프로그램에서 앞으로 근로 자들을 대상으로 소음 노출로 인한 청력손실, 보호구 착용법 등 에 관한 교육이 적극적으로 실시되어야 할 것이다.

중심 단어 : 직업적 소음성 난청·청력손실·청력보호·청력보존 프로그램.

\section{Ethical Statement}

This study was approved by the Institutional Review Board of Hallym University of Graduate Studies (IRB \# HUGSAUD 513742).

\section{Acknowledgments}

The authors thank to the participants.

\section{Declaration of Conflicting Interests}

There are no conflict interests.

\section{Funding}

N/A

\section{Author Contributions}

All authors took responsibility for the integrity of the data and equally contributed to this work. C.Y. and J.B. designed and wrote the paper. C.Y. collected and analyzed data. J.B. revised the manuscript. And C.Y. and J.B. discussed the results together and implications at each stage.

\section{ORCID iDs}

Cheol Min Yoon

https://orcid.org/0000-0001-6775-3064

Junghwa Bahng

\section{REFERENCES}

Bhumika, N., Prabhu, G., Ferreira, A., \& Kulkarni, M. (2013). Noise-induced hearing loss still a problem in shipbuilders: A cross-sectional study in Goa, India. Annals of Medical and Health Sciences Research,

$3(1), 1-6$.

Buksh, N., Nargis, Y., Yun, C., He, D., \& Ghufran, M. (2018). Occupational noise exposure and its impact on worker's health and activities. International Journal of Public Health and Clinical Sciences, 5(2), 180-195.

Canadian Centre for Occupational Health and Safety. (2018, December 5). Noise-Occupational Exposure Limits in Canada. Canada.ca. Retrieved from https://www.ccohs.ca/oshanswers/phys_agents/exposure_can. html

Colbeth, H. L., Zeig-Owens, R., Liu, Y., Webber, M. P., Schwartz, T. M., Hall, C. B., et al. (2019). Persistent self-reported ear and hearing problems among World Trade Center-exposed firefighters and emergency medical service workers, 2001-2017-A longitudinal cohort analysis. American Journal of Industrial Medicine, 62(1), 43-49.

Danhauer, J. L., Johnson, C. E., Dunne, A. F., Young, M. D., Rotan, S. N., Snelson, T. A., et al. (2012) Survey of high school students' perceptions about their iPod use, knowledge of hearing health, and need for education. Language, Speech, and Hearing Services in Schools, 43(1), 14-35.

Fuente, A. \& Hickson, L. (2011). Noise-induced hearing loss in Asia. International Journal of Audiology, 50 Suppl 1, S3-S10.

Kim, K. (2016). Noise induced hearing loss in Korea. Audiology and Speech Research, 12 Suppl 1, S17-S20.

Korea Occupational Safety and Health Agency. (2005, December) Establishing a Hearing Conservation Program, Implementation Guidelines. H-40-2005. KOSHA. Retrieved from https://oshri.kosha.or.kr/cms/ board $/$ Download.jsp?fileId $=34467$.

Le, T. N., Straatman, L. V., Lea, J., \& Westerberg, B. (2017). Current insights in noise-induced hearing loss: A literature review of the underlying mechanism, pathophysiology, asymmetry, and management options. Journal of Otolaryngology-Head and Neck Surgery, 46(1), 41.

Lee, J. H. (2017). Proceedings from The Korean Society of Occupational and Environmental Medicine 59th conference: Field Research to Identify Improvements in Hearing Conservation Programs (pp. 231-232). Seoguipo.

Lee, J. S. \& Bahng, J. (2016). A survey and development of a questionnaire related to assess habits of using personal device, knowledge of hearing loss and attitude of hearing protection in adolescents. The Journal of the Acoustical Society of Korea, 35(1), 24-34.

Ministry of Employment and Labor. (2018, May). 2016 Workers Health Checkups Results (11-1492000-000029-10). Ministry of Employment and Labor. Retrieved from https://kiha21.or.kr/?mod=document\&uid= 2817\&page_id=120.

Neitzel, R. L., Swinburn, T. K., Hammer, M. S., \& Eisenberg, D. (2017). Economic impact of hearing loss and reduction of noise-induced hearing loss in the United States. Journal of Speech, Language, and Hearing Research, 60(1), 182-189.

Nelson, D. I., Nelson, R. Y., Concha-Barrientos, M., \& Fingerhut, M. (2005). The global burden of occupational noise-induced hearing loss. American Journal of Industrial Medicine, 48(6), 446-458.

Occupational Safety and Health Administration. (2018, December 5). Occupational Noise Exposure. United States Department of Labor. Retrieved from https://www.osha.gov/SLTC/noisehearingconservation/.

van Kempen, E. E., Kruize, H., Boshuizen, H. C., Ameling, C. B., Staatsen, B. A., \& de Hollander, A. E. (2002). The association between noise exposure and blood pressure and ischemic heart disease: A meta-analysis. Environmental Health Perspectives, 110(3), 307-317. 


\section{APPENDIX}

\section{청력손실 이해, 청력보호, 청력보존 프로그램의 이해에 관한 연구}

1. 아래 중 해당하는 것에 동그라미 쳐주거나 숫자로 답을 기입하세요.

1) 나는 남 / 여, 나이는 만 세이다.

\section{사회력, 과거 질병력}

1) 나는 음주를 (1) 거의 마시지 않는다 (2) 조금 마신다(주 1 2회 이하) (3) 자주 마신다(주 3 4회 이상)

2) 나는 흡연을 (1) 전혀 안 피움 (2) 피운다 ( 개피/하루)

(3) 끊었다[( 개피/하루)씩 총 ( )년간 피우다 ( )년 전에 끊었다]

3) 경험이 있는 질환에 모두 체크해주세요.

(1) 심장병 (2) 고혈압 (3) 고지혈증 (4) 불면증 (5) 결핵 (6) 류마티스 질환 (7) 당뇨병 (8) 신장병 (9) 암 (10) 우울증

(11) 해당 없음

4) 이비인후과에서 진단받거나 수술받은 경험이 있는 질병에 모두 체크해주세요.

(1) 난청 (2) 이명 (3) 중이염 (4) 고막천공 (5) 안면마비 (6) 메니에르병 (7) 고막 수술 (8) 없음

\section{현재 근무지에서의 소음 노출 관련}

1) 나의 근무 연수는 년이다.

2) 내가 느끼기에 소음 작업장 내 하루 평균 소음 노출시간은 약 시시간이다.

(평균적으로 작성해주시면 됩니다.)

3) 나는 업무 간 청력보호 기기는 잘 착용하고 있다.

매우 그렇다( $80 \%$ 이상 착용) / 그렇다(50 80\% 미만 착용) / 보통이다(50\% 정도 착용) /

그렇지 않다(20 50\% 미만 착용) 매우 그렇지 않다(20\% 미만 착용)

\section{2. 청력손실 원인의 이해}

\begin{tabular}{|l|l|l|l|l|}
\hline & \multicolumn{1}{|c|}{ 질 문 } & 그렇다 & 아니다 & 모르겠다 \\
\hline 1 & $\begin{array}{l}\text { 청력손실을 가지고 있는 사람은 이미 청각기관이 손상돼서 유해한 소음 수준에 대해 염 } \\
\text { 려하지 않을 것이다. }\end{array}$ & & \\
\hline 2 & 소음 때문에 발생한 청력손실은 예방할 수 있었다. & & & \\
\hline 3 & 귀에서 윙윙 울리는 것은 유해한 소리의 과다 노출에 대한 경고 신호이다. & & \\
\hline 4 & 상대방의 음성이 작거나 웅얼거리게 들리면 청력에 문제가 있을 것이다. & & \\
\hline 5 & 주변에 자주 큰 소리가 나더라도 내 귀는 스스로 청력을 보호할 수 있는 능력이 있다. & & & \\
\hline 6 & 큰 소리에 의한 청력손실이 발생한 사람은 보청기를 착용하면 정상적으로 들을 수 있다. & & & \\
\hline 7 & 큰 소리에 의한 청력손실이 발생한 사람은 소리가 커지면 정상적으로 들을 수 있다. & & & \\
\hline 8 & 청력의 보호는 청력손실이 발생한 사람에게 도움이 되지 않는다. & & \\
\hline 9 & 면이나 휴지를 귀에 넣는 것은 큰 소리로부터 청력을 보호하는 좋은 방법이다. & & & \\
\hline
\end{tabular}


3. 청력보호 인식에 관한 태도

\begin{tabular}{|c|c|c|c|c|}
\hline \multicolumn{1}{|c|}{ 질 문 } & 그렇다 & 아니다 & 모르겠다 \\
\hline 1 & 청력손실 방지에 대하여 노력하는 것은 가치가 있다. & & & \\
\hline 2 & 청력손실 방지를 위하여 돈을 쓸 가치가 있다. & & & \\
\hline
\end{tabular}

\section{4. 청력보존 프로그램에 관한 이해}

\begin{tabular}{|l|l|l|l|l|}
\hline & \multicolumn{1}{|c|}{ 질 문 } & 그렇다 & 아니다 & 모르겠다 \\
\hline 1 & 청력보존 프로그램에 대해서 들어본 적이 있다. & & & \\
\hline 2 & 해당 작업 장소의 소음 수준에 대해서 설명을 들었고 인지하고 있다. & & & \\
\hline 3 & 청력보호 기기의 착용 방법 및 주의사항에 대해 알고 있다. & & & \\
\hline 4 & 소음 건강장해 방지에 필요한 사항에 대해 알고 있다. & & & \\
\hline 5 & 본인의 청력검사 및 의학적 판정에 대해 이해하고 있다. & & & \\
\hline
\end{tabular}

